\title{
An Investment Analysis Based on Main Commodities and The Effect of Licensing System, Availability of Manpower, and Economic Growth on Investment Realization in Jambi
}

\author{
Muhammad Safri ${ }^{1}$ and M. Syurya Hidayat ${ }^{2}$ \\ ${ }^{1}$ Faculty of Economic and Business, University of Jambi, Jambi, Indonesia \\ $\square$ (e-mail) m_syafri@unja.ac.id \\ ${ }^{2}$ Faculty of Economic and Business, University of Jambi, Jambi, Indonesia, \\ $\bowtie$ (e-mail) m_syuryahidayat@unja.ac.id
}

\begin{abstract}
To realize its investment, the Province of Jambi must have an information feasibility that can guide the investment feasibility study. They required preliminary data on preeminent commodities in the districts/cities, descriptions of the land types suitability and factors that are expected to affect investment realization. Each city and district has different land suitability data. The five districts studied generally have two types of soil, namely, red yellow podozolic soil and peat soil (organosol). The city of Jambi has more regional advantages compared to other districts because it is supported by a strategic location, has appeals to investors due to the elevated location and the distribution of the inlands/districts. Muaro Jambi regency as the main zone city should be able to anticipate the city faster development for example by developing palm oil or rubber derivation industry with red yellow podzolic condition. The similar case applies to the upstream of West Tanjung Jabung which needs to be prioritized and investment promotion breakthrough. Whereas, the downstream of West Tanjung Jabung is expected to capture investment opportunities in fishery or aquatic sub-sector. East Tanjung Jabung needs to apply to investment opportunities in oil and liquid gas and so on, in addition to utilizing the potential of transportation infrastructure to and from Berhala island. Similarly, the potential of mangrove forests in Berbak National Park, can be packed into al natural tourism sustainable power.
\end{abstract}

Keywords: main commodities, licensing system, availability of manpower, and economic growth, and investment realization

\section{Introduction}

Indonesia is one of the developing countries and must catch up with increased investment (Fakhruddin and Malisa, 2017). It is necessary to realize that the selection of leading sectors is not merely to be different according to the various characteristics of the region, but especially the acceleration strategy of regional development itself in the form of comparative advantage and competitive advantage. In identifying and developing the potential of the leading sectors of the regency and municipality areas, it is necessary to pay attention to six matters: 1) development level linkages, 2) inter-sectoral linkages, 3) contribution to sectors or economic structures, 4) employment, 5) human resources and technology and 6) non-economic strategic considerations (Word Bank, 2016).

The Jambi investment analysis (supply side) is expected to be one of value-added tools for assessing and formulating business and investment opportunities that can be implemented by the private sector in the region and can also create a form of targeted, planned and targeted investment program (Eliza, 2018).

Jambi investment potential information is relatively inadequate and adequate for the stakeholders to go further realize their investment desire, relative investment plan is always unbalanced with the realization of investment. The study also intends to provide additional information on the identification 
of business sectors, commodities and locations that are capable of having bright prospects in the future, so that they can be developed by investors and for the Jambi provincial government as the basis for policy making.

\section{Methods}

Data collection for this study was carried out at places that provide secondary data required as reference materials such as the Central Bureau of Statistics (Badan Pusat Statistik-BPS) of Jambi and regencies/cities. A strong theoretical foundation is needed in problem solving so that decisions can be made from the collection of books, journals, scientific articles, data from the Internet and others related to this work.

Location Quotient (LQ) analysis was used for identifying the economic base (base sector) of a region. This analysis can help to find out how big the level of specialization of the sector of base or superior (leading sector) in a region. LQ analysis measures the concentration of an economic activity within a region by comparing its role in the regional economy with the role of similar economic activities on a wider scope (regional or national). The superior sector analysis obtained through the combined approach is combined with the analysis of land suitability (type of soil) contained in five cities and districts in Jambi (East Jambi area), namely, city of Jambi, Batanghari regency, Muaro Jambi, West Tanjung Jabung regency and East Tanjung Jabung regency.

The Klassen typology or four quadrant analysis was used to see the position of a district/city against the province in terms of the regional income per capita as well as economic growth. The sector side of analysis was divided into four sectors. The per capita income is described as an abscissa and the province's economic growth is the coordinate line.

The next method of analysis was conducted using multiple linear regression analysis. This type of quantitative analysis was used to find out how the influence of several independent variables such as one door integrated service permit system (PTSP), the total availability of manpower in Jambi and the growth of economic to investment realization in Jambi as a whole.

\section{Results and Discussion}

The calculation result with LQ method shows that the basic sectors in city of Jambi consist of 14 sectors (Jambi Centre Bureau of Statistics, 2016). This is known from the analysis of the average LQ from 2010 to 2016 which has more than one value. The sectors that are based on the highest to lower LQ are respectively transport and warehousing (4.10), electricity and gas procurement (3.62), large and retail trade, car and motorcycle repair (2.76), company services (2.71), financial services and insurance (2.66), health services and social activities $(2,29)$, administration of government, defense and social security compulsory (2.23), provision of accommodation and drinking (16), water supply, waste management, waste and recycling (1.96), real estate (1.78), information and communication (1.52), education services (1.44), and construction (1.37).

Meanwhile, the non-bases sector in Jambi consists of agriculture, forestry and fishery sectors, mining and quarrying sector, and other services. The number of base sectors in Jambi is higher because the city of Jambi is the capital of the Province of Jambi. The city of Jambi is the main plant in Jambi Province which has a high hierarchical value of the number and core of basic infrastructure, supporting or complementary. A high hierarchy is the main attraction for the investors to come to plan their investment. The city of Jambi with the altitude of an average area under $100 \mathrm{~m}$ asl, is supported by the commodity distribution stream or services from the hinterland area, i.e. other districts in Jambi province. Hinterland area as a supplier of industrial raw materials and its industrial location is in the area of Jambi City. Investors in this relationship prefer the market oriented approach or product outlet (market oriented). In terms of rent area, Jambi city has the advantage of the strategic value of the region (locational rent). 
The results of calculation by LQ method show that the base sector in regency of Muaro Jambi only consist of 4 categories from the highest to the lowest LQ values are agricultural sector, with 1.01, processing industry sector 1.50, financial sector and leasing services company 1.55 , mining and quarrying sector 1.74, manufacturing industry 1.03, respectively. Non-base sectors in Muaro Jambi district or with an average LQ value of less than one, include electricity and gas, water supply, building, hotel and restaurant trade, finance, leasing and other services and services.

Muaro Jambi regency is generally included in the central area of Jambi province with an average height of $500 \mathrm{~m}$ above sea level and some located at an altitude of $100 \mathrm{~m}$ above sea level. The soil type in Muaro jambi is mostly red yellow podzolic soil (ultisol, USDA Taxanomy, 1975, in Harjowigeno, 1997). Land in this district is mostly planted with palm and rubber. Almost $65 \%$ of the people work in the plantation sector, whether as owners, workers. The management of this plantation sector is managed by the government, the private sector and the community. However, the potential of the existing area is only in the upstream palm oil industry in the form of palm oil factory and rubber business which is also in upstream. The total area of rubber plantation is 60,686 h.a., palm oil is 31,233 ha. There are two main roads that cross Muaro Jambi, namely the East and West Cross. The potential value of the strategic value of the location, should be filled with palm and or rubber derivative industries both of which can be aimed at filling the global market share.

The economy of Muaro Jambi regency in 2016 has accelerated after experiencing a slowdown the previous year. The growth rate of PDRB Muaro Jambi in 2016 reached 5.43 percent increase compared to the year 2015 which reached 5.25 percent growth. The highest economic growth was achieved by Health and Social Services category of 7.79 percent. All economic categories of PDRB Muaro Jambi regency in 2016 recorded a positive growth.

Based on the calculation of LQ method, the base sector in Batang Hari regency consists of 6 categories, including agriculture, forestry and fisheries with LQ 1.56, education service with LQ 1.43 value, health service and social activity with LQ value 1.24, mandatory government administration, defense and social security with LQ value of 1.15, other services with LQ value of 1.13 and manufacturing industry with LQ value of 1.12 .

Fishery sub-sector is very potential to be developed, either inland fisheries or other freshwater fisheries in the lakes. Still in the fishery sub sector, in Muaro Jambi can be realized a big freshwater aquarium in Sumatra, and fish flour industry from raw material jabal catfish are cultivated by many people.

Distance from city of Jambi to the city of Kuala Tungkal, the capital of West Tanjung Jabung regency about $127.8 \mathrm{~km}$. Agriculture is the prominent sector of this district. Based on existing data, the area of oil palm plantation here is recorded 90,244 ha with 12 units of palm oil factory with the main result of crude palm oil (CPO) and palm kernel (kernel). Production of other plantation sub-sector is coffee $(2,596$ ha), deep coconut (54,725 ha), areca nut (pinang) (10,556 ha).

The potential of this district with the production of palm plantation, because the existing land in the form of red yellow podzolic soil (PMK) in the upstream and peat soil in the downstream area. Soil PMK in the upstream is very suitable for plantation such as oil palm plantations, while in downstream area consists of peat soil (organosol) suitable for deep heads, area coconut, fishery and so on.

The potential of marine fishery resources is currently 22,367.9 tons with a fleet of nearly 1000 units. However, all the results that have been utilized are still in extractive order, have not been processed in a downstream industry that can provide added value and multiplier effect on the economic growth of the region and the community such as palm oil - downstream industry in the form of butter, cosmetics etc., fish canning industry or paint industry etc. LQ values of more than one, biased to less than one if the area is not creative to develop industry from existing commodities or services. If the calculation approach is done with oil and gas, then oil and gas is the top seed of West Cape. Currently oil 
production has been in the position of 5,514.23 barrels per day with the absorption of about 700 workers. The absorption of local worker is in a state of unskilled labor in general.

Base sector in East Tanjung Jabung regency, based on LQ calculation of GRDP value based on constant price by sectors from 2010 to 2016, shows that only category of mining and excavation become its superior sector. Regency that is a fraction of this Tanjung Jabung regency, should be keen to catch downstream investment from oil and gas such as LPG industry. The natural tourism sector to Berhala island should be developed through the structuring of infrastructure and facilities. The same water potential with the parent regency, should be targeted to be realized in the medium term become the priority of shrimp farming, canning fish and so on.

Based on the results of Klassen Typology analysis of 2016 on five districts/cities which is the study area, including Jambi, Muaro Jambi, Batang Hari, West Tanjung Jabung and East Tanjung Jabung regencies indicate that only Batang Hari regency that is classified as fast-forward and fast-growing areas. This is evident from the rate of economic growth and per capita income which is higher than the economic growth rate and per capita income of province Jambi.

Other areas that enter the rapidly growing region classification are Jambi city and Muaro Jambi, although having a per capita income is lower than the figure of the province, but the economic growth rate of the two districts is higher than the provincial economic growth rate. That is, the city of Jambi and Muaro Jambi regency is a rapid developed area with that area potential. Meanwhile, East Tanjung Jabung and West Tanjung Jabung regencies are classified as advanced but depressed, meaning that in the future the growth will not be so fast although the potential for development is basically very large. The ground transportation of these two districts to and from the neighboring provinces is not as good as other districts within Jambi province. Sea transportation routes are not working as expected. This is evident from the economic growth below the province but the per capita income above the province.

The following is the multiple results of the licensing system variables (one stop services/PTSP), total availability of man power and economic growth as independent variables that effect Jambi's investment realization as dependent variable:

$$
\begin{aligned}
Y & =96.59540+1.833787 X_{1}+16.72824 X_{2}+0.162416 X_{3} . \\
R_{2} & =0.746373
\end{aligned}
$$

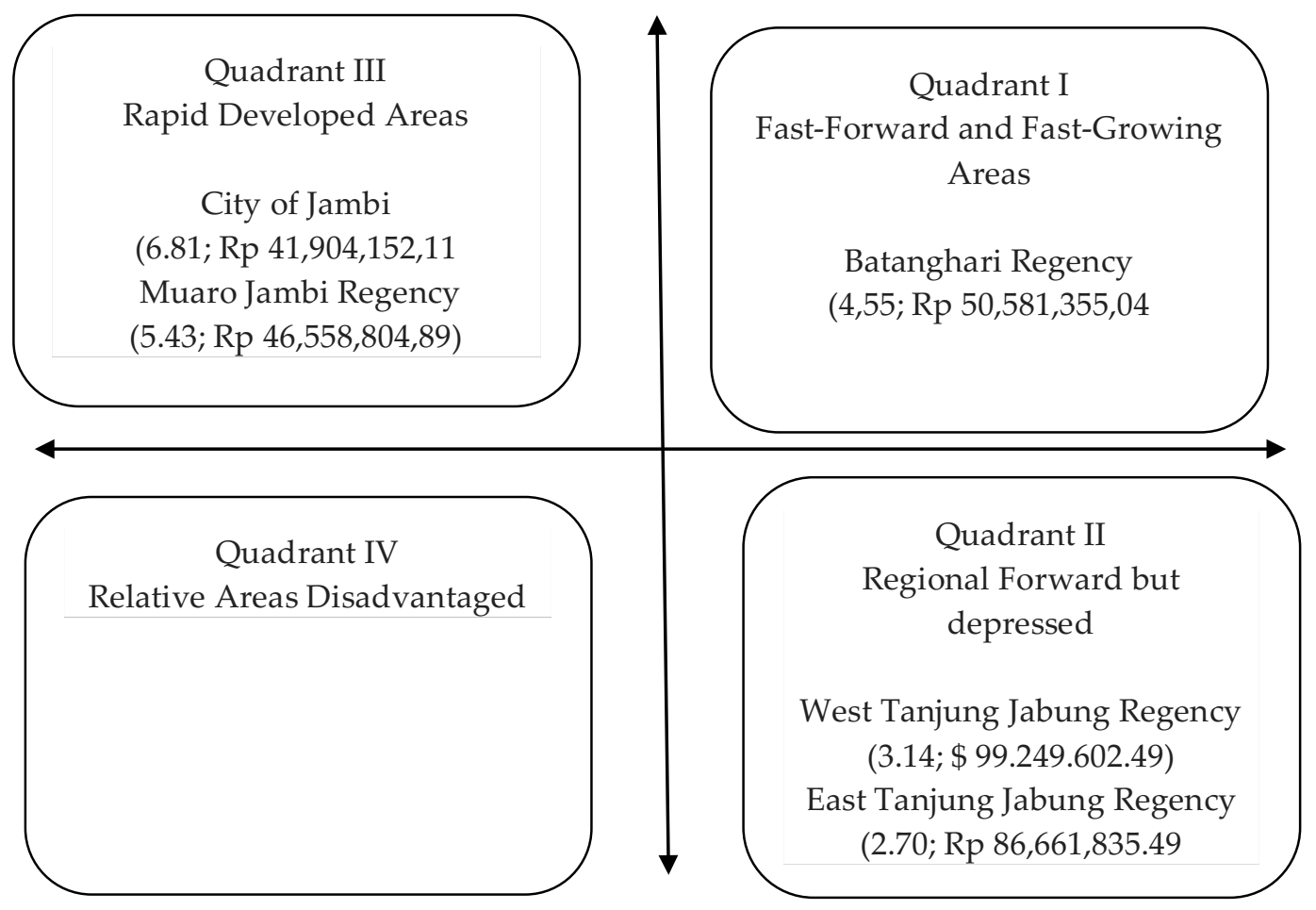

Figure1 Klassen typology matrix 
The results of the model show the magnitude of the coefficient of determination of 0.746373 . This can be interpreted that the amount of realized of investment in Jambi province as a simultaneously influenced by economic growth, labor, and PTSP equal to $74.63 \%$. While $25.37 \%$ of the amount of realized of investment is influenced by other variables that are not researched by the researcher.

Partially, one-stop service /PTSP $\left(X_{1}\right)$ has a significant effect on investment realization in Jambi province (Y). The probability value is smaller than the value of $\alpha=10 \%$. The results of this study are similar with previous research that's conducted by Abdul (2016), which shows that PTSP variable has a positive and significant impact on the realization of investment in Lampung province. Furthermore, the results of Maslihati (2016) suggests that the quality of licensing has a significant and positive effect on the increase of investment in East Java Province. Any increase in the performance of the service system will be able to increase the inflow of investment. The research is an empirical normative research with descriptive research type. Research conducted by researchers in line with the World Bank theory that one that encourages the realization of investment is to provide ease in investment licensing for investors. The policy of facilitating investment licensing is by establishing one-stop integrated service (PTSP) in Indonesia.

The availability of manpower $\left(\mathrm{X}_{2}\right)$ has also a significant and positive impact on the increase of investment in Jambi. The number of manpower in Jambi has a positive effect for investors to realize their investment in Jambi. This condition is different from the findings of research results by Wijayanti and Yusuf (2009) in the city of Semarang. Every increase in manpower as much as one person is not significant effect on investment sector industry in city of Semarang.

Finally, economic growth $\left(X_{3}\right)$ has a significant and positive effect on the realization of investment in Jambi (Y). The results of Dewi and Triaryati research (2015) are similar to the results of this study. But they examined the effect of economic growth on direct investment.

\section{Conclusions}

Based on the analysis and discussion, obtained some conclusions as follows. The advantages of city of Jambi in attracting investment opportunities is due to the high hierarchy region, in terms of number and types of infrastructure and market orientation. Muaro Jambi regency with its red yellow podsolic soil type (PMK) has land suitability for the same plantation commodity with Batanghari regency, but the investment realization in both areas is still of primary sector and there is no downstream industry from $\mathrm{CPO}$ or from crumb rubber. The same type of soil in upstream area of West Tanjung Jabung regency also potential for palm oil plantation and downstream industry of CPO but not yet realized significant results. The downstream area of West Tanjung Jabung regency which is rich in fishery resources is also not yet developed from fishery and marine products. East Tanjung Jabung regency is superior for oil and gas industry, but this industry and its downstream industry have not been realized. The value added and multiplier effect are still lower. PTSP during the research period, significant effect on the realized of investment. Manpower during the research period has a significant effect on the realization of investment. This means that one unit of increase in manpower has an effect on the increase of investment in Jambi, but the qualification of local workers is absorbed generally in not so good qualification.

To further enhance the added value and multiplier impacts of commodity benefits that have been generated by each district, it is recommended that each district make a breakthrough policy on the development of CPO and / or rubber and fishery industries in West Tanjung Jabung and or downstream industries of oil and gas for East Tanjung Jabung by creations utilizing the potential of nature tourism such as Berbak National Park that is unique and specific. Jambi provincial government, would more intensify the socialization of regional maps of commodities that not only based on land suitability, but based on global market. The Government will follow up the significant increase in the number of workers affected by the realization of investment in Jambi through integrated policies and strategies to improve the quality of human resources in Jambi Province with the establishment of regional superior- 
based polytechnics and labor market orientation. It is necessary to continuously make the simplification of investment licensing service in Jambi as such as online licensing application that can be monitored intensively especially by potentials investors.

\section{Acknowledgments}

The corresponding author would like to acknowledge the funding support from the Ministry of Research, Technology and Higher Education, Republic of Indonesia research grant (Hibah RISTEKDIKTI). The authors would also show sincere gratitude to various parties who have helped both directly and indirectly from the beginning to the completion of the research. Acknowledgments are conveyed specifically to the reviewer team who have passed the research proposal and support friends through constructive criticism.

\section{References}

Dewi, K., \& Triaryati, N. (2015). Pengaruh pertumbuhan ekonomi, suku bunga dan pajak terhadap investasi langsung. Jurnal Online Manajemen Unud, 4(4), 866 - 878.

Eliza, Mesayu. (2013). Analisis pengaruh variabel makro ekonomi terhadap investasi asing di Indonesia. Retrieved from http://jurnal.ub.ac.

Fakhruddin \& Malisa, M. (2017). Analisis investasi langsung di Indonesia. Jurnal Ilmiah Mahasiswa Ekonomi Pembangunan, 2(1), 116 - 124. Fakultas Ekonomi dan Bisnis Unsyiah.

Gujarati, N. Damodar., \& Dawn C. Porter. (2013). Dasar-Dasar Ekomektrika Edisi 5. Jakarta: Salemba Empat.

Center Bureau of Statistics (BPS). (2018). Jambi in Figure. Annual Publications.

Maslihatin, E. (2016). Dampak kualitas pelayanan perizinan terhadap peningkatan investasi pada UPT pelayanan perizinan terpadu di Propinsi Jatim. Jurnal Kebijakan dan Manajemen Publik, 4(2).

Peraturan Presiden No. 27 Tahun 2009 tentang Pelayanan Terpadu Satu Pintu di Bidang Penanaman Modal. World Bank. (2016). Doing Business Indonesia 2016. Retrieved from http://www.doingbusiness.org/

Wijayanti, Yusuf. (2010). Pengaruh ketersediaan tenaga kerja, infrastruktur, pendapatan per kapita, terhadap investasi industri di Kota Semarang. Retrieved from http://eprint.undip.ac.id/29482 /1/JURNAL.pdf. 